\title{
Ecosystem services and hydroelectricity in Central America: modelling service flows with fuzzy logic and expert knowledge
}

\author{
Bruno Locatelli • Pablo Imbach · Raffaele Vignola • \\ Marc J. Metzger · Efraín José Leguía Hidalgo
}

Received: 28 December 2009/Accepted: 16 August 2010/Published online: 1 September 2010

(C) The Author(s) 2010. This article is published with open access at Springerlink.com

\begin{abstract}
Because ecosystem services are generally not produced and used in the same place, their assessment should consider the flows of services from ecosystems to users. These flows depend on the characteristics and spatial distribution of ecosystems and users, the spatial relationships between them, and the presence of filters or barriers between ecosystems and users. The objective of this paper is to map the ecosystem services provided to the Costa Rican and Nicaraguan hydroelectric sectors, which are crucial sectors for national sustainable development and depend directly on hydrological ecosystem services. The paper presents an approach for modelling the flows of
\end{abstract}

B. Locatelli ( $\square)$

CIRAD UPR Forest Resources, 34398 Montpellier, France

e-mail: bruno.locatelli@cirad.fr

B. Locatelli

CIFOR, Bogor 16000, Indonesia

P. Imbach $\cdot$ R. Vignola

CATIE Climate Change Program, 7170 Turrialba, Costa Rica

R. Vignola

ETH Zurich, Institute for Environmental Decisions, 8092 Zurich, Switzerland

\section{J. Metzger}

Centre for the Study of Environmental Change and

Sustainability (CECS), School of GeoSciences,

University of Edinburgh, Drummond Street,

Edinburgh EH8 9XP, UK

\section{E. J. L. Hidalgo}

CATIE Climate Change Program,

7170 Turrialba, Costa Rica

\section{E. J. L. Hidalgo}

Instituto de Investigaciones de la Amazonía Peruana,

Pucallpa, Peru multiple services from diverse ecosystems to diverse users through different kinds of filters in a landscape. The approach uses expert knowledge and fuzzy numbers to handle uncertainties. The analyses for Costa Rica and Nicaragua show how the approach helps identify priority areas for the conservation and restoration of forests for the services they provide to the hydroelectric sector. As such, it is a useful tool for defining spatially targeted policies for the conservation of ecosystem services and for involving the users of ecosystem services in ecosystem management.

Keywords Watershed services - Hydroenergy · Hydrology $\cdot$ Landscape $\cdot$ Forest

\section{Introduction}

People depend on services provided by ecosystems, which can be classified as provisioning services (e.g., fibre, fuel wood, or genetic resources), regulation services (e.g., climate, disease, or water regulation), and cultural services (e.g., recreation, education, or heritage) (Costanza et al. 1997; Daily 1997; Millennium Ecosystem Assessment 2003, 2005). The extensive degradation of ecosystems caused by human activities over the past 50 years has placed increasing importance on ecosystem conservation and management to sustain the supply of services (Kremen 2005; Millennium Ecosystem Assessment 2003).

Despite their importance for human well-being, ecosystem services are often underrepresented in policy decisions, mainly because of market failures and lack of awareness. Valuation studies, monetary or not, can demonstrate the worth of ecosystem services to policymakers deciding on land use and natural resource management (Meyerson et al. 2005; Tomich et al. 2004; Troy and 
Wilson 2006). Furthermore, identifying the ecosystems that provide services to communities or economic sectors may promote investment in ecosystem conservation and management by service users (Gren et al. 2010; Naidoo and Ricketts 2006).

The supply of ecosystem services is often unevenly distributed in a landscape. It is therefore important to consider spatial heterogeneity in the targeting of policy interventions (van der Horst 2006; van Jaarsveld et al. 2005; Wünscher et al. 2008). Knowing the spatial distribution of service supply may also facilitate comparison with other land use priorities or opportunity costs for evaluating conflicts or synergies (Troy and Wilson 2006). Maps of ecosystem services can also be associated with maps of ecosystem vulnerability to human pressures and climate change for targeting adaptation policies or evaluating the effects of environmental changes on ecosystems and society (Metzger et al. 2008; Metzger and Schröter 2006).

Previous studies have mapped the spatial distribution of ecosystem services (e.g., Ferraro 2004; Hein et al. 2006; Troy and Wilson 2006; Yang et al. 2003). For instance, Eade and Moran (1996) conducted a spatial valuation of the Rio Bravo Conservation Area in Belize, taking into account the heterogeneity of ecosystem characteristics (e.g., soils and vegetation for hydrological services or biomass for carbon sequestration). In addition to the spatial distribution of ecosystems, the characteristics of service users must be considered for generating maps of ecosystem services that go beyond mapping their functions (Egoh et al. 2007).

Because most ecosystem services are often not produced and used in the same place, assessment studies should consider the flows of services from ecosystems to users (i.e., social groups and economic agents benefiting from ecosystem services) in the space where services are delivered. Naidoo et al. (2008) emphasized the need for maps representing where ecosystem services are produced and where they benefit nearby and distant users. The flows of ecosystem services to population or economic agents depend on the physical nature of services. For instance, global climate regulation by carbon sequestration in any place benefits the world population; flood protection benefits only downstream populations or activities located near rivers or floodplains; and pollination services flow in a small radius around the ecosystem (Daly and Farley 2004; van Jaarsveld et al. 2005). Previous studies have dealt with flows of services; for instance, Guo et al. (2000) assessed water regulation services in a river basin through a spatially explicit hydrological model that considered the flows of services from the ecosystems to a hydroelectric dam.

Assessing ecosystem services at a fine resolution is relevant for decision-making but requires a good representation of spatial flows (Strayer et al. 2003). Three important factors have to be considered in the assessment of ecosystem services and their spatial flows at fine resolution: (1) the characteristics and spatial distributions of ecosystems and users, (2) the spatial relationships between them (i.e., which ecosystems provide services to a user and which users receive services from an ecosystem), and (3) the presence of filters or barriers between ecosystems and users (for instance, a lake in the case of hydrological services) (van Noordwijk et al. 2004). In studies at coarser resolutions, flows are not an issue because ecosystems and users are assumed to be in the same region, as in the case of the Advanced Terrestrial Ecosystem Analysis and Modelling project (ATEAM) for Europe (Metzger et al. 2008; Metzger and Schröter 2006).

Because of the complexities of economic and ecological systems, it is very costly, and sometimes impossible, to quantify the level of service provision by an ecosystem or the well-being generated by the service (Carpenter and Turner 2000; Chee 2004; Freeman 2003; Limburg et al. 2002; Polasky et al. 2005). Even if the focus is on only one economic sector in a country, mapping ecosystem services is complex because it involves diverse types of ecosystem services, ecosystems, and users of services. For example, developing hydrological and economic models for all of a country's catchments and water users (e.g., drinking water facilities, agro industry, and hydroelectric plants) is difficult in a context of scarcity of data on hydrological regimes and the production functions of the economic agents. The use of hydrological models in ungauged basins is a promising approach to overcome data scarcity problems (e.g., Mwakalila 2003), but the extrapolation of information from gauged to ungauged basins remains challenging in a context of diverse climates, landscapes, and ecosystems (Wagener et al. 2004). In addition, assessing hydrological ecosystem services also requires developing economic models of water users and coupling them to hydrological models, which is also challenging (Kragt et al. 2010). For identifying hotspots of ecosystem services at the scale of a country, simpler approach can be used.

In this paper, the focus is on hydrological services and the hydroelectric sector. In many countries, hydroenergy presents both great potential and challenges for sustainable development (Frey and Linke 2002). The hydroelectric sectors are directly dependent on hydrological ecosystem services, such as the regulation of water quantity and the reduction in soil erosion and sedimentation (Kaimowitz 2005). Mapping the priority areas of ecosystem services for hydroelectricity production (i.e., places where ecosystem degradation can affect negatively or ecosystem restoration can affect positively the sectors) can foster investment in ecosystem conservation or restoration by the energy sector.

The objectives of this paper are (1) to develop a method for mapping ecosystem services provided to the 
hydroelectric sector at the national scale and (2) to apply the method for determining the priority areas for ecosystem conservation and restoration and analysing synergies between conservation efforts (protected areas) and the provision of ecosystem services to the hydroelectric sector in Costa Rica and Nicaragua. The method considers the spatial modelling of flows of multiple services produced by diverse ecosystems and benefiting diverse users. As judgement is inevitable in a context of data scarcity and uncertainties (Heal et al. 2004), the method uses expert knowledge elicitation and fuzzy numbers. The elicitation of stakeholder values or expert knowledge has already been used for mapping ecosystem services (e.g., Raymond et al. 2009; Kragt et al. 2010). Bayesian network modelling techniques have been applied for integrating knowledge about hydrological, ecological, and economic aspects of catchment management (Kragt et al. 2010). In this paper, fuzzy techniques are used for handling mathematically ambiguous data (Lawry 2006; Phillis and Andriantiatsaholiniaina 2001; Zadeh 1965) and have already been applied to formalizing expert knowledge on hydrology (e.g., Droesen 1996).

\section{Materials and methods}

\section{Study area}

The study was conducted at the national scale in two Central American countries: Costa Rica and Nicaragua (see maps in Fig. 6). The Central American climate is tropicalequatorial with many areas receiving more from 2,000 to 3,000 $\mathrm{mm}$ of rainfall per year (Griesinger and Gladwell 1993) but with droughts affecting frequently some areas of the region, especially in the Pacific watershed. Water resources are crucial to the sustainable development of the region. For instance, major economic sectors, such as agriculture and energy, depend heavily on water availability. Watershed management has been promoted in the region and innovative mechanisms have been implemented, such as payment for ecosystem services (Kaimowitz 2005).

In Central America, hydroelectricity is a major source of energy and large investments are at stake. In Costa Rica, hydroenergy production has increased by $82 \%$ since 1995 (CEPAL 2006). In 2005, the hydroelectric sector represented a total capacity of 1,304 MW (66\% of the country's capacity for energy production) and $80 \%$ of the actual production. In Nicaragua, the production has not increased since 1995 and hydroelectricity represented only 104 MW (14\% of the country's capacity for energy production) and $14 \%$ of the actual production in 2005 (CEPAL 2006). Nicaragua had only two operating plants in 2007 but started promoting the development of hydroenergy in order to reduce its dependence on imported fossil fuels. As a result, 40 plants are currently under design and were included in this study.

The basic spatial units of the study are microcatchments with a mean area of $1.3 \mathrm{~km}^{2}$. Costa Rica and Nicaragua were divided into 43,000 and 103,000 microcatchments, respectively, using a detailed topographic map to set their boundaries and hydrological networks (TNC 2007).

\section{Eliciting expert knowledge}

Nineteen Central American experts were interviewed: six from hydroelectric companies and 13 from research centres and universities (six working on ecology and seven on hydrology). All interviews followed the same guidelines. Initial discussions dealt with the research objectives. Subsequent discussions dealt with appropriate typologies of ecosystems, ecosystem services, filters, and service users. It was agreed that five types of ecosystems should be considered: cloud forests, lowland and low hill forests, woodlands (ecosystems with low tree density, including wooded savannas, agroforestry, and silvopastoral systems), grasslands (including savannas and pastures), and croplands. Cloud forests were distinguished from other forests because of their hydrological particularities (Bruijnzeel 2004) and their significant areas in the two countries (Mulligan and Burke 2005). For mapping ecosystems, existing land use and ecosystem maps were used (ITCR 2004; MagFor 2002; Mulligan and Burke 2005).

The experts identified three relevant ecosystem services: the conservation of total water yield, the conservation of base flow (i.e., conserving water flows during the dry season), and the reduction in soil erosion (i.e., avoiding downstream siltation by protecting soils against soil erosion). They defined three types of filters (i.e., landscape elements that affect the flow of ecosystem services from ecosystems to users): dams, lakes, and major superficial water intakes (e.g., pumping stations and canals for irrigation). Experts agreed that dams and lakes are important filters as they affect base flows and can trap sediments, thus making downstream users less directly influenced by the ecosystems upstream of filters. Experts proposed to include water intakes if monthly extraction exceeded $25 \%$ of the river base flow, estimated roughly as the average upstream water balance (precipitation minus evapotranspiration) during the six driest months of the year. Data on the location and extracted volumes of water intakes (for irrigation, industrial, commercial, and domestic uses) were retrieved from consultations with national institutions. ${ }^{1}$ The water balance was estimated from WorldClim climate

\footnotetext{
${ }^{1}$ AyA, ITCR, ICE, INEC.
} 
data (Hijmans et al. 2005), with a spatial resolution of one square kilometre, which is similar to the resolution of the microcatchment map (1.3 sq km).

Regarding the typology of service users (i.e., companies in the hydroelectric sector), the experts proposed to distinguish two types of plants managed by these users: hydroelectric dams (reservoir-type projects) and run-ofriver plants (with little or no storage capacity). Other kinds of hydroelectric plants defined by Egré and Milewski (2002), e.g., pumped-storage projects, were considered irrelevant for Costa Rica and Nicaragua. Information on the location, type, and capacity of hydroelectric plants was retrieved from documents and databases of energy companies or ministries. ${ }^{2}$

Once typologies were agreed upon, the 19 experts were asked to rate the production of each service by each ecosystem type, the utility of each service to each user type (i.e., the ability of a service to satisfy one or more needs or wants of the user), and the effect of each filter type on the flow of each service. Experts expressed their degree of agreement with statements such as "Ecosystem X contributes to conserving base flows". All experts answered all questions. The answers were collected using a five-level Likert scale (strongly disagree, disagree, neither agree nor disagree, agree, strongly agree). Experts' opinions were converted into fuzzy triangular numbers in the interval $[0,1]$. A fuzzy number is represented by a function showing a degree of membership $\mu$ (Fig. 1): a degree of zero means that the value is not in the set of possible values, whereas a degree of one means that the value is completely in the set (Cox 1994). The two end-points of the fuzzy interval were the lower and upper quartiles of experts' answers, and the peak point was the median value.

Mapping ecosystem services and priorities

for conservation and restoration

The flows of ecosystem services were mapped using the conceptual framework shown in Fig. 2, where the variables production, flow, and utility are fuzzy numbers derived from experts' knowledge and the variables area and presence are spatial data. The level $Q_{r}\left(s, p_{d}\right)$ of ecosystem service $s$ received by the destination spatial unit $p_{d}$ depends on the production of services by ecosystems in the upstream catchments and the capacity of services to flow from the ecosystem to the destination spatial unit (Eq. 1).

\footnotetext{
2 In Nicaragua: CNE (Comisión Nacional de Energía), Ingeniería y Ciencia Ambiental, INE (Instituto Nicaragüense de Energía). In Costa Rica: ICE (Instituto Costariciense de Electricidad), ITCR (Instituto Tecnológico de Costa Rica).
}

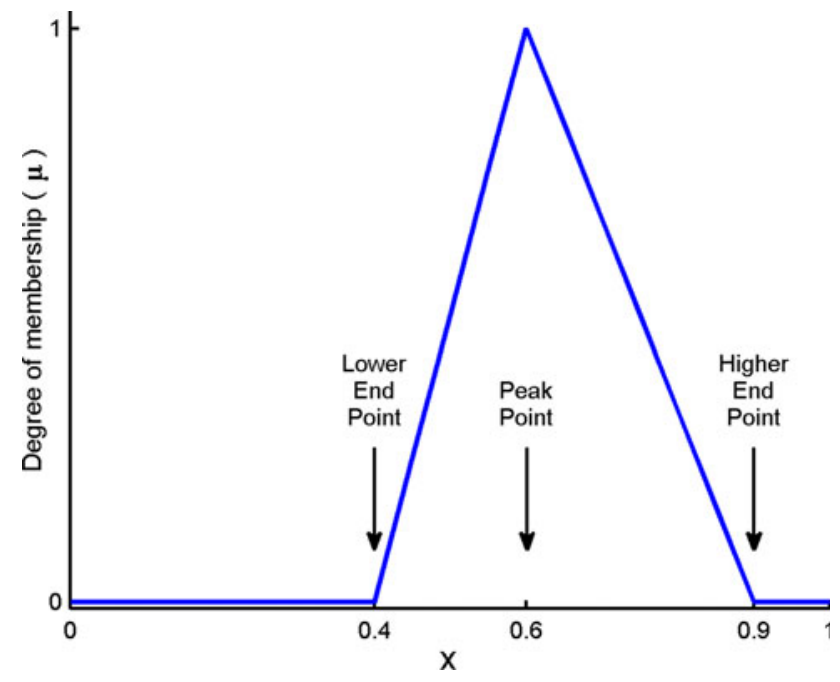

Fig. 1 Representation of fuzzy numbers (in this example, the degree of membership of 0.3 in the set of value is zero, which means that it is impossible that $x$ equals 0.3 , whereas it is partially possible that $x$ equals 0.5 and totally possible that $x$ equals 0.6 )

$Q_{r}\left(s, p_{d}\right)=\frac{\sum_{p_{o} \in \text { upstream }\left(p_{d}\right)} \sum_{e} \operatorname{area}\left(p_{o}, e\right) \cdot \operatorname{production}(e, s) \cdot f l o w\left(s, p_{d}, p_{o}\right)}{\sum_{p_{o} \in \operatorname{upstream}\left(p_{d}\right)} \sum_{e} \operatorname{area}\left(p_{o}, e\right)}$

where

- $Q_{r}\left(s, p_{d}\right)$ is the level of ecosystem service $s$ received by the destination spatial unit $p_{d}$;

- $\operatorname{upstream}\left(p_{d}\right)$ is the set of origin spatial units $p_{o}$ providing services to the destination spatial unit $p_{d}$;

- $\operatorname{area}\left(p_{o}, e\right)$ is the area of ecosystem type $e$ in the origin spatial unit $p_{o}$ (each unit can be occupied by different ecosystem types);

- production $(e, s)$ describes the capacity of ecosystem type $e$ to produce service type $s$

- $\operatorname{flow}\left(s, p_{d}, p_{o}\right)$ describes the capacity of service type $s$ to flow from $p_{o}$ to a downstream spatial unit $p_{d}$. It equals 1 if there is no filter in the path between $p_{o}$ and $p_{d}$. Otherwise, it equals (1-filter $\left.\left(s, p_{o}, p_{d}\right)\right)$ where filter(po, $p d)$ is the capacity of the filters between $p_{o}$ and $p_{d}$ to affect the flow of service $s$, as expressed by the experts.

The utility $U$ of all ecosystems in the country for the whole hydroelectric sector was then calculated, assuming that, for one service and one user of this service, the utility is proportional to the level of service received, the utility of the service for the user, and the presence of the user (measured as the production capacity of the hydroelectric plant) (Eq. 2).

$U=\sum_{p_{d}} \sum_{u} \sum_{s}$ presence $\left(u, p_{d}\right) \cdot \operatorname{utility}(s, u) \cdot Q_{r}\left(s, p_{d}\right)$ 
Fig. 2 Representation of the flows of ecosystem services in a landscape: ecosystems, filters, and users

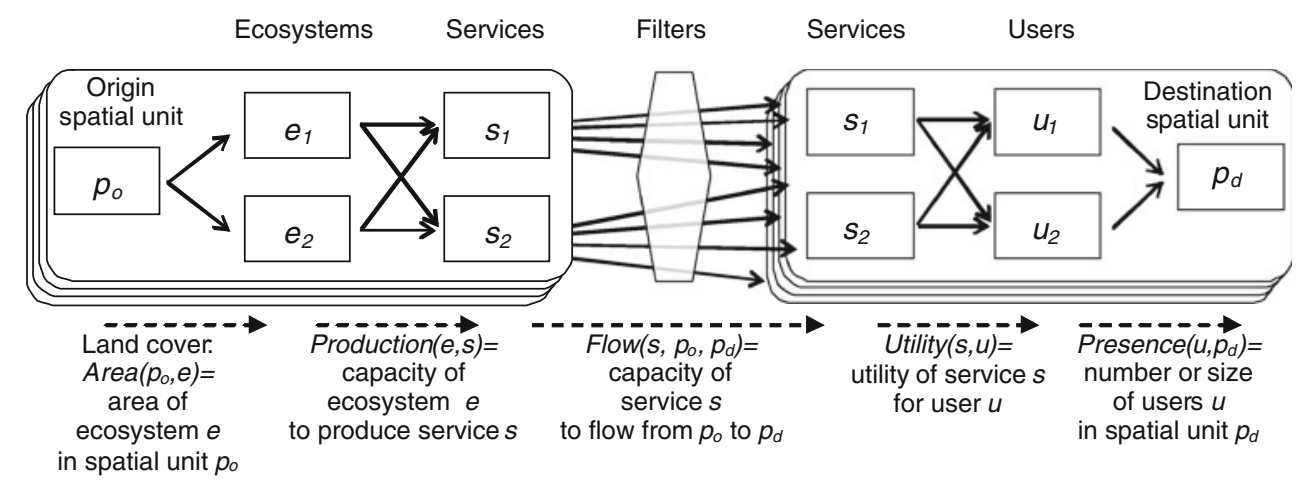

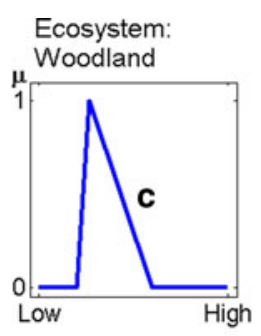
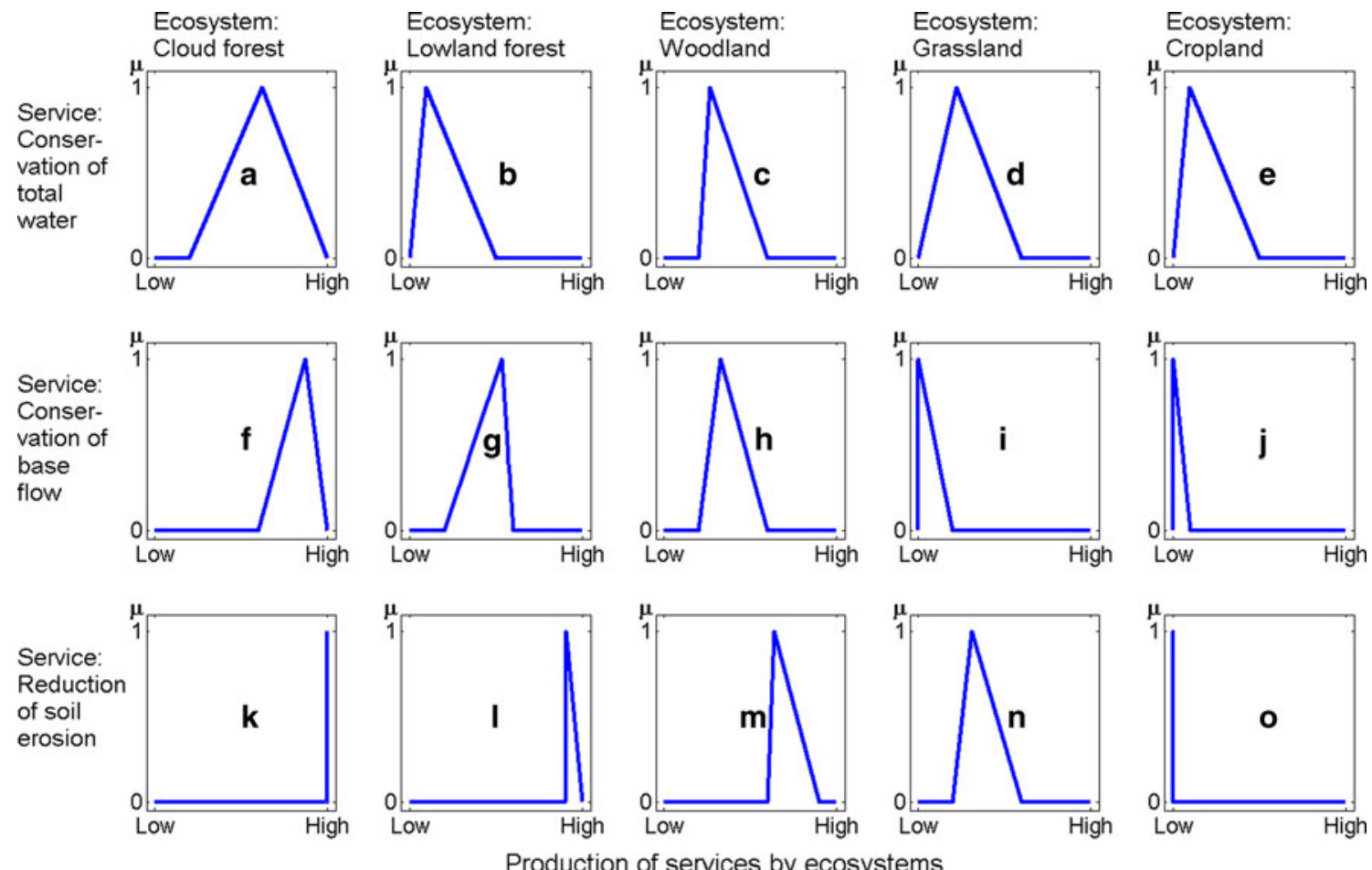

Fig. 3 Fuzzy numbers expressing expert knowledge on the production of services by ecosystems ( $\mu$ is the degree of membership described in the "Materials and methods" section)

where

- $\operatorname{presence}\left(u, p_{d}\right)$ describes the presence (here, in terms of production capacity) of user type $u$ in the destination spatial unit $p_{d}$;

- $\operatorname{utility}(s, u)$ describes the utility of service $s$ for user $u$;

- $Q_{r}\left(s, p_{d}\right)$ is the level of ecosystem service $s$ received by the destination spatial unit $p_{d}$.

The marginal utility of each spatial unit (i.e., the change in utility caused by a change in the services provided by this unit) was then assessed by modifying the ecosystems in this spatial unit in two ways. First, in each spatial unit, one by one, forests (cloud and lowland) were converted into a mix of croplands and grasslands, to determine the marginal utility of existing forests in this unit and the priority for forest conservation (Eq. 3). Second, croplands and grasslands were converted into forests (cloud forests or lowland forests, depending on the location ${ }^{3}$ ), to determine the marginal utility of potential forests and the priority for forest restoration (Eq. 4).

Forest_Conservation_Priority $(p)=U-U_{\text {deforested } \_p} p$

Forest_Restoration_Priority $(p)=U_{\text {restored } \_p}-U$

where

\footnotetext{
3 The climate envelope of cloud forests was delimited using the current distribution of these forests.
} 
- $U_{\text {deforested } p}$ is the utility of all ecosystems to the whole hydroelectric sector, with forests in the spatial unit $p$ being replaced by croplands and grasslands;

- $U_{\text {restored } \_p}$ is the utility of all ecosystems to the whole hydroelectric sector, with the croplands and grasslands in the spatial unit $p$ being replaced by forests.

Initial data and final results were pre-processed and visualized in ArcMap (ESRI); calculations were carried out in Matlab 2008 (Mathworks). The equations were applied using fuzzy arithmetic operators (Hanss 2005). Finally, the results were defuzzified using the centre of gravity method (Wang and Luoh 2000) and ranked for each country separately. The location of priority areas (defined as the $25 \%$ top-priority areas in each country) was analysed, for instance their location in protected areas. The location of protected areas was taken from existing maps (MagFor 2002; ITCR 2004).

\section{Results and discussion}

\section{Eliciting expert judgement}

Expert judgement on the production of services by ecosystems (Fig. 3) was in line with scientific analyses on the role of forests in hydrological cycles (Andreassian 2004; Bonell and Bruijnzeel 2005; Bosch and Hewlett 1982; Bruijnzeel 2004; Calder 2002; Locatelli and Vignola 2009; Sahin and Hall 1996). Contrary to popular belief, the total water yield is generally lower in a forested catchment than in a catchment under other land uses, because of the high evapotranspiration of forests (Bruijnzeel 2004). This was recognized by the experts (Fig. $3 \mathrm{~b}$ compared to $3 \mathrm{c}$ or $3 \mathrm{~d}$ ). Cloud forests have a different effect on total water yield to other natural forests because of their capacity to intercept horizontal precipitation from the clouds, as pointed out by the experts (Fig. 3a) and in the literature (Bruijnzeel 2001). Regarding the conservation of base flow, experts gave low values to grasslands and croplands because of their lower infiltration rate of water in soil, compared with forest ecosystems (Ilstedt et al. 2006) (Fig. 3f-j). However, the literature reports uncertainties regarding the effect of forest on base flow, as this effect results from two competing processes: high transpiration by forests, contributing to a low base flow, and high infiltration under forests, contributing to soil water recharge and high base flow (Calder 2002; Bruijnzeel 2004). The effect of ecosystems on the reduction in soil erosion was assumed to be high under forests and low in croplands, with intermediate values for woodlands and grasslands (Fig. 3k-o), in line with the literature (e.g., Bruijnzeel 2004).
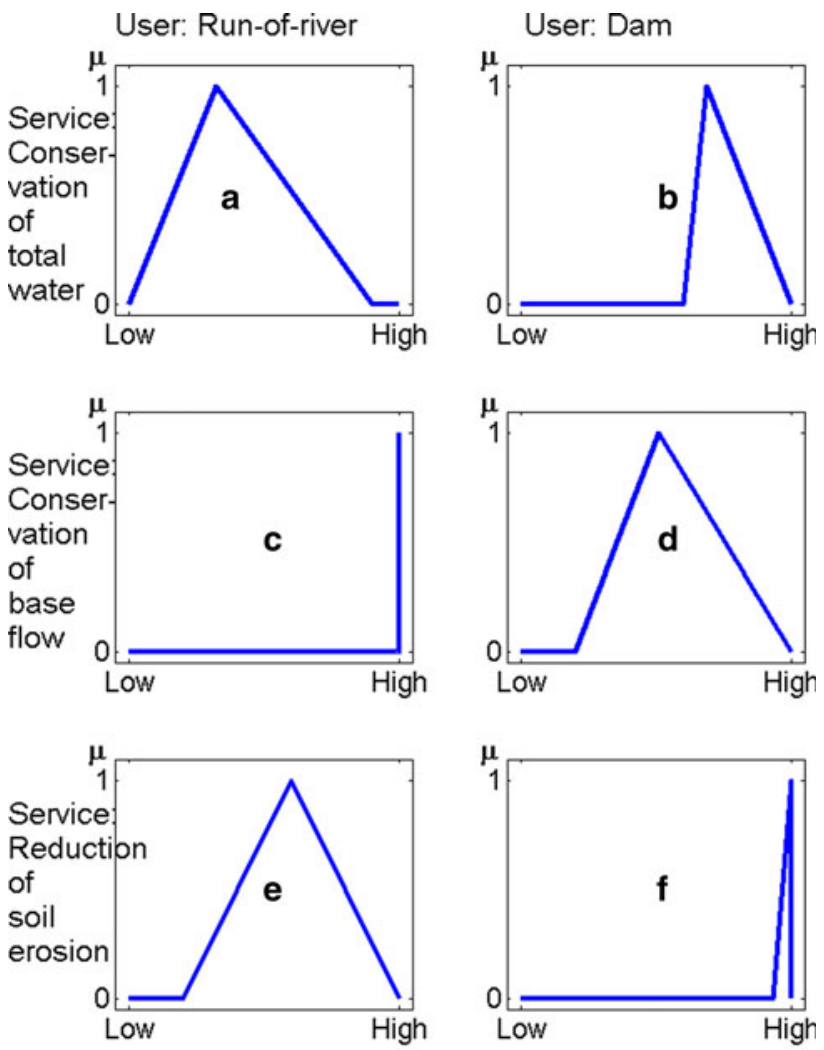

Utility of services for users

Fig. 4 Fuzzy numbers expressing expert knowledge on the utility of services for users ( $\mu$ is the degree of membership described in the "Materials and methods" section)

Expert judgement confirmed that the different ecosystem services do not have the same utility for the different hydroelectric plants, as concluded by other authors (e.g., Guo et al. 2000; Muñoz and Sailor 1998; Southgate and Macke 1989). The consulted experts recognized that a dam depends more on total water yield than on water regularity because of its storage capacity (Fig. 4b, d). They also argued that reducing erosion is highly relevant to dams (Fig. 4f), because sediment load in water reduces the storage capacity of dams, clogs generator intake, and wears out turbines (Veloz et al. 1985). Conversely, the experts said that the preservation of base flow is crucial for run-of-river plants, because of the absence of storage capacity (Fig. 4c). Sediment load can also represent a cost for these plants but, according to the experts, to a lesser extent than for dams (Fig. 4e). Regarding filters, the experts considered that significant water intakes strongly affect base flows and, to a lesser extent, total water (Fig. 5a,d) and that lakes and dams trap sediment (Fig. 5h, i).

Some answers differed significantly in correlation with the expertise of the respondents $(p<0.01)$. When asked about the capacity of ecosystems to conserve total water yield, experts in the hydroelectric sector perceived higher 
Fig. 5 Fuzzy numbers expressing expert knowledge on the effect of filters on the flows of services ( $\mu$ is the degree of membership described in the "Materials and methods" section)
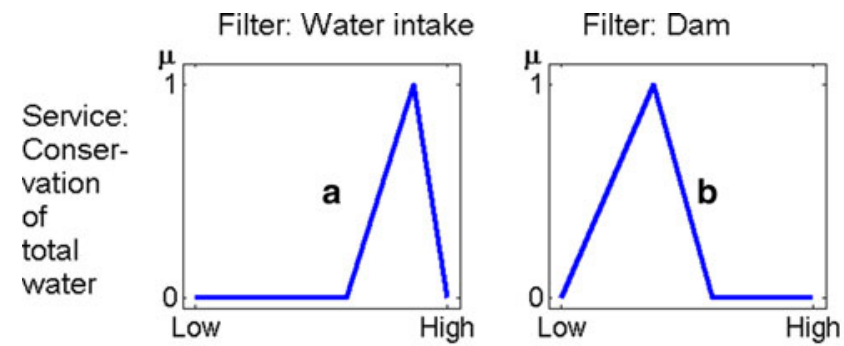

Filter: Lake
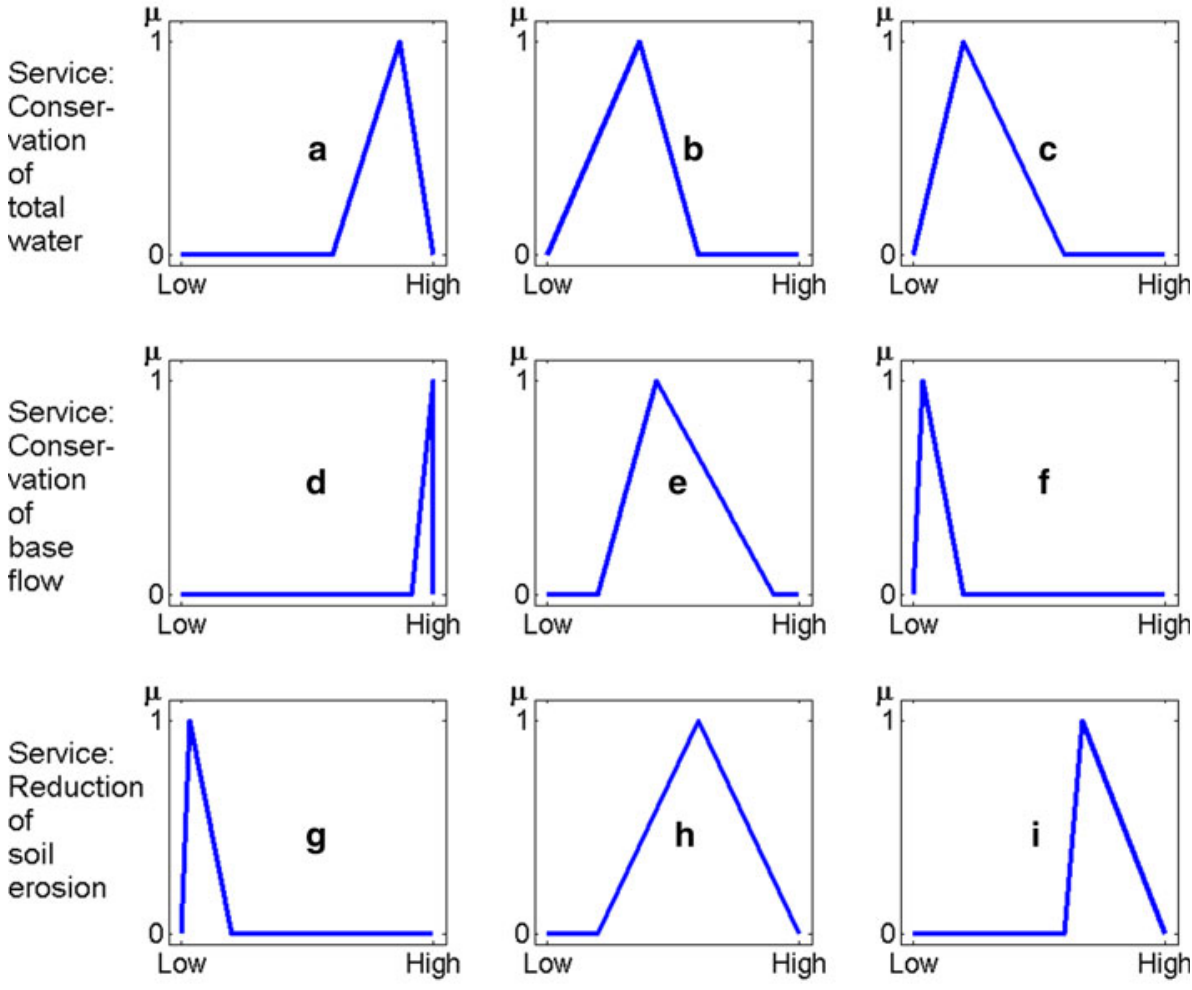

Effect of filters on services

capacity for cloud forests, and lower capacity for grasslands and croplands, than did experts in ecology or hydrology. Experts in the hydroelectric sector placed more importance on conserving total water yield for run-of-river plants than did experts in ecology or hydrology.

Mapping ecosystem services and priorities for conservation and restoration

Priority areas for forest conservation and restoration for the hydroelectric sectors are concentrated around a few nuclei, as only $13 \%$ of the country area in Costa Rica and $28 \%$ in Nicaragua are located upstream of hydroelectric plants (Figs. 6 and 7). In Costa Rica, the river basins upstream of the plants are smaller than in Nicaragua, in part because of the steep terrain and the location of many hydroelectric plants in the mountains in Costa Rica.

In Costa Rica, the forest conservation priority areas for the hydroelectric sector are located in the mountain range in the centre of the country, especially the upper parts of the Reventazon river basin and the tributary basins of the San Juan river, namely Rio Zapote, Rio San Carlos, and Rio Sarapiqui (Fig. 6). Around 31 and $24 \%$ of the priority areas for forest conservation are located in the upper parts of the Reventazon and San Juan river basins, which host, respectively, 27 and $25 \%$ of the hydroelectric capacity of the country (Table 1). Within the three river basins with the highest priority for conservation (Reventazon, San Juan, Terraba), priority areas are located at high altitudes (from 930 to 2,330 m). In Costa Rica, almost all forests in priority areas for conservation are cloud forests. Regarding restoration in Costa Rica, around $26 \%$ of the priority areas are located in the Reventazon river basin and $23 \%$ in Tarcoles, the second most important river basin for restoration (Table 1 and Fig. 7). In the Reventazon river basin, the restoration priority areas are at lower altitudes (from 1,160 to $1,840 \mathrm{~m}$ ) than the altitudes for conservation priorities $(1,220$ to $2,330 \mathrm{~m})$.

In Nicaragua, the priority areas for forest conservation are located in the central north, especially in the Rio Grande de Matagalpa river basin, which hosts $49 \%$ of the planned national hydroelectric capacity (Fig. 7). Around 65 and $27 \%$ of the priority areas for forest conservation are located in the mid-parts of the Matagalpa river basin (most of them between 230 and $350 \mathrm{~m}$ ) and the upper parts of the San Juan river basin (above $740 \mathrm{~m}$ ) (Table 1 and Fig. 6). Priority areas have both cloud forests and lowland forests (59 and 41\%, respectively). Regarding forest restoration in Nicaragua, around 77 and $17 \%$ of priority areas are located in the Matagalpa and San Juan river basins, respectively (Table 1).

In each country, one river basin emerges as a major priority for both conservation and restoration. In Costa Rica, the Reventazon river basin hosts 31 and $26 \%$ of the 
Fig. 6 Major river basins and priority areas for forest conservation for the provision of ecosystem services to hydroelectric sectors in Nicaragua and Costa Rica

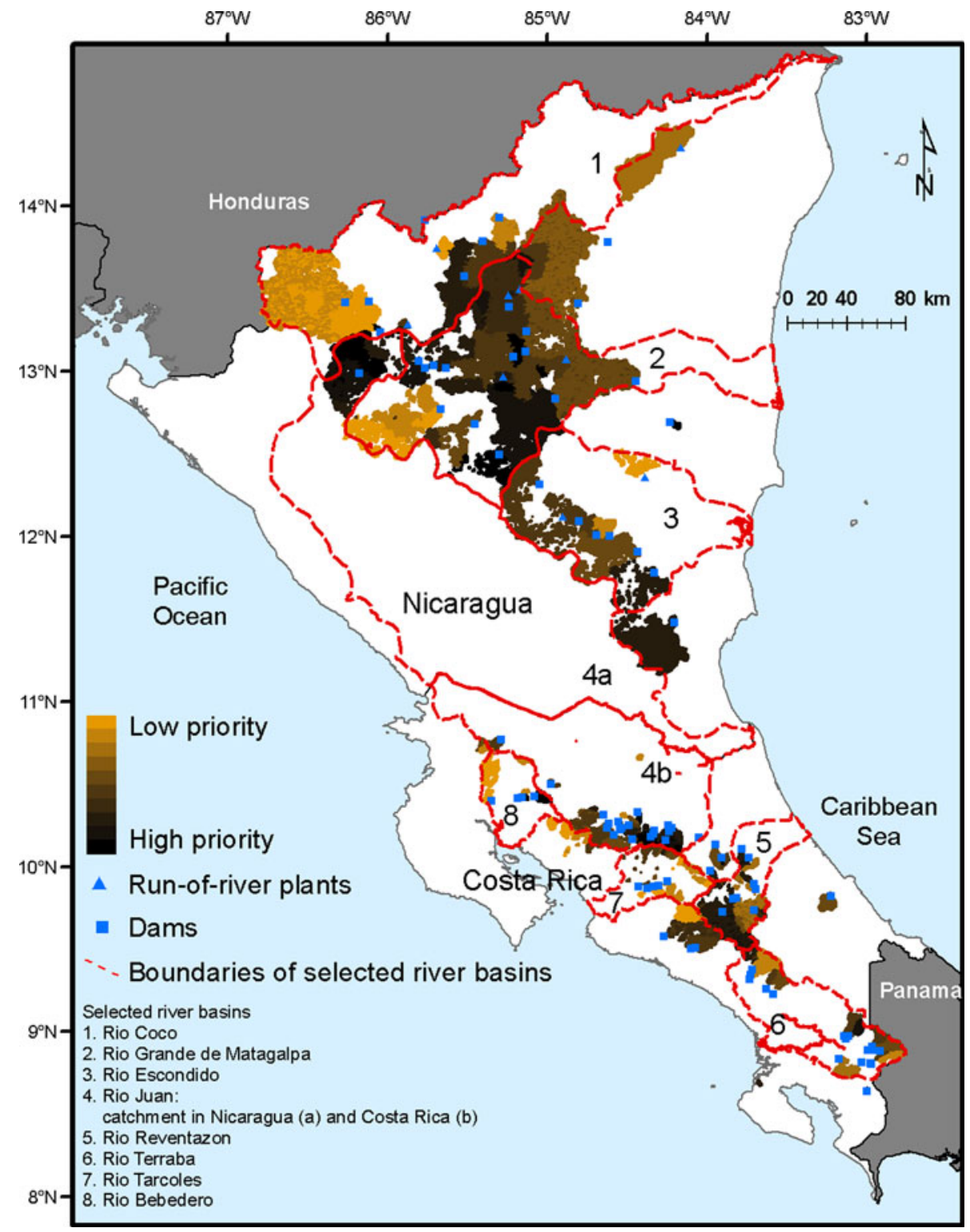

priority areas for conservation and restoration, respectively, even though it covers only $6 \%$ of the country. This importance and the different altitudes for the two priorities can be explained by the economic activities and land use patterns in the river basin, especially the presence of large hydroelectric plants, the dominance of agriculture and livestock breeding at low and mid-altitudes, and the large areas of cloud forests at high altitude. In Nicaragua, the Matagalpa river basin holds 65 and $77 \%$ of the priority areas for conservation and restoration, respectively. The distinction between conservation and restoration priority areas in terms of altitude is not as clear as in the Reventazon (Table 1). The central part of the river basin is more suitable for conservation as it is covered by forests, whereas restoration priorities are more in the southern part.
In Costa Rica, top-priority river basins for conservation and restoration have similar patterns: conservation priorities for the upper parts, restoration priorities for the middle parts. This can be explained by the topography and human activities, as most hydroelectric dams are located in or around the central mountains, where agriculture and livestock breeding are highly developed at low and medium altitudes and forests have not been preserved at high altitudes. In Nicaragua, no clear differences can be observed between conservation and restoration in terms of altitude, because of non-altitudinal patterns of land uses and human settlements.

In Costa Rica, spatial congruence was observed between protected areas and the priority areas for the conservation of ecosystem services provided to the hydroelectric sector 
Fig. 7 Major river basins and priority areas for forest restoration for the provision of ecosystem services to hydroelectric sectors in Nicaragua and Costa Rica

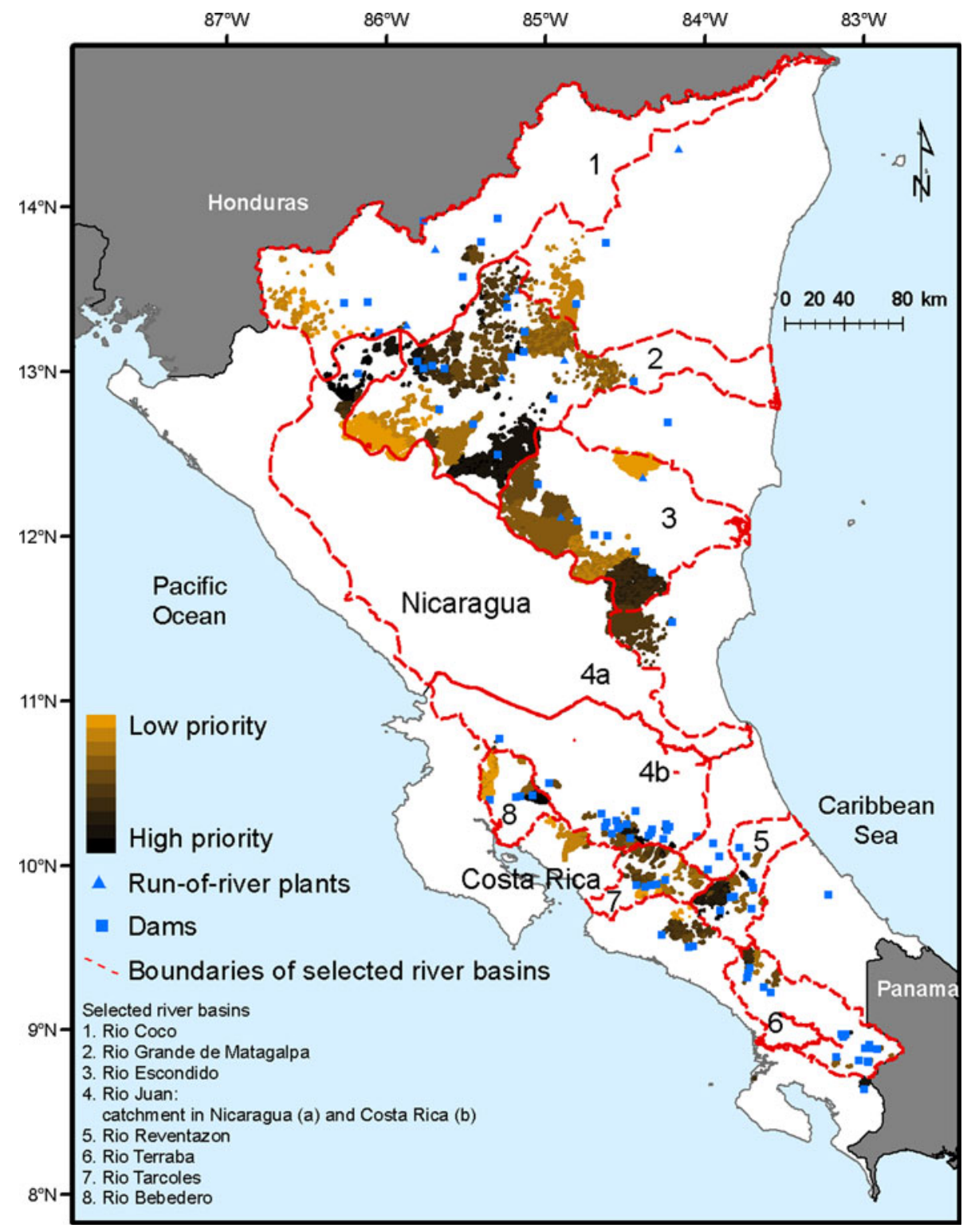

(Table 2 where the kappa coefficient is 0.32 and chi-square test results in $p<0.001)$. This can be explained by the fact that many Costa Rican protected areas are located upstream of hydroelectric plants, partly because of institutional factors. For instance, in the 1960s, the major Costa Rican hydroelectric company was involved in the creation of national parks in upstream river basins. ${ }^{4}$ No spatial congruence was observed between protected areas and priority areas in Nicaragua.

\footnotetext{
${ }^{4}$ Personal communication of Manuel Corrales, former executive of ICE (Instituto Costarricense de Electricidad).
}

\section{Conclusion}

In this paper, a method was presented for mapping ecosystem services provided to hydroelectric sectors at the national scale. This method considers that different ecosystems have different capacities to produce distinct ecosystem services and that different services have different utility to distinct service users. In addition, it focuses on the spatial relationships between ecosystems and service users, as well as the presence of filters in the flows of services from ecosystems to service users. As data scarcity made it difficult to model hydrological processes in all the catchments of each country or to study the production function of all hydroelectric plants, expert knowledge was used to represent the production of services by ecosystems, the effect of filters on service flows, and the utility of the 
Table 1 River basins with high-priority areas for the provision of ecosystem services to hydroelectric sectors

\begin{tabular}{|c|c|c|c|c|c|}
\hline \multirow[t]{2}{*}{ River basin } & \multirow{2}{*}{$\begin{array}{l}\text { Percentage of national } \\
\text { hydroelectric capacity }\end{array}$} & \multicolumn{2}{|c|}{ Priority areas for forest conservation } & \multicolumn{2}{|c|}{ Priority areas for forest restoration } \\
\hline & & $\begin{array}{l}\text { Percentage of conservation } \\
\text { priority areas in the country }\end{array}$ & $\begin{array}{l}\text { Altitude range } \\
\text { (in metres asl) }(*)\end{array}$ & $\begin{array}{l}\text { Percentage of restoration } \\
\text { priority areas in the country }\end{array}$ & $\begin{array}{l}\text { Altitude range } \\
\text { (in metres asl) }(*)\end{array}$ \\
\hline \multicolumn{6}{|l|}{ Costa Rica } \\
\hline Reventazon & 27 & 31 & $1,220-2,330$ & 26 & $1,160-1,840$ \\
\hline San Juan & 25 & 24 & $930-1,510$ & 17 & $700-1,480$ \\
\hline Bebedero & 16 & 1 & $470-720$ & 11 & $300-620$ \\
\hline Terraba & 11 & 23 & $1,430-2,290$ & 8 & $1,240-2,030$ \\
\hline Tarcoles & 11 & 4 & $1,120-1,830$ & 23 & $670-1,410$ \\
\hline Others & 10 & 17 & $1,220-1,980$ & 15 & $1,280-1,850$ \\
\hline \multicolumn{6}{|l|}{ Nicaragua } \\
\hline Matagalpa & 49 & 65 & $230-350$ & 77 & $280-480$ \\
\hline San Juan & 13 & 27 & $740-1,060$ & 17 & $600-1,030$ \\
\hline Escondido & 11 & 3 & $210-280$ & 5 & $170-230$ \\
\hline Coco & 5 & 3 & $900-1,070$ & 2 & $950-1,070$ \\
\hline Others & 22 & 2 & $70-470$ & 0 & - \\
\hline
\end{tabular}

(*) Lower and upper quartiles of the altitudes of the priority areas

Table 2 Areas with high and low priority inside and outside the protected areas in Costa Rica

\begin{tabular}{llr}
\hline $\begin{array}{l}\text { Areas (in } \mathrm{km}^{2} \text { and percentage } \\
\text { of the total area of the country) }\end{array}$ & $\begin{array}{l}\text { Inside } \\
\text { protected } \\
\text { areas }\end{array}$ & $\begin{array}{r}\text { Outside } \\
\text { protected } \\
\text { areas }\end{array}$ \\
\hline $\begin{array}{l}\text { High-priority areas } \\
\text { for conservation } \\
\text { (25\% top priority) }\end{array}$ & $\begin{array}{r}590 \mathrm{~km}^{2} \\
(1.2 \%)\end{array}$ & $\begin{array}{r}330 \mathrm{~km}^{2} \\
(0.6 \%)\end{array}$ \\
$\begin{array}{l}\text { Low-priority areas for } \\
\text { conservation (25\% } \\
\text { bottom priority) }\end{array}$ & $350 \mathrm{~km}^{2}$ & $770 \mathrm{~km}^{2}$ \\
$(0.7 \%)$ & $(1.5 \%)$
\end{tabular}

services to users. Because of the ambiguities associated with these variables, the approach used fuzzy numbers for making qualitative judgements explicit and handling them mathematically.

The application of this approach to Costa Rica and Nicaragua identified priority areas for conservation and restoration of forests for the services they provide to the hydroelectric sector. As such, it is a useful and costeffective approach for defining spatially targeted policies for the conservation of ecosystem services and facilitating the involvement of the users of ecosystem services in ecosystem management. In addition, the approach involves experts from the concerned sectors, which may increase the research's impact on decision-making.

Compared to hydrological and economic modelling, an approach based on expert knowledge and fuzzy numbers requires less data but does not allow drawing conclusions on the economic consequences of conservation and restoration. It does not allow either studying the economic trade-offs between different land use and the ecosystem services they provide to economic agents. As a prioritization tool, the approach can help identifying river basins where data collection and detailed analysis, based on hydrological and economic modelling, can be conducted.

Acknowledgments The authors thank the 19 experts who took part in our survey and Luis Molina Carpio, Carlos Perez, Francisco Alpizar, Juan Robalino, Richard Woodward, Olga Corrales, María Angélica Naranjo, and Manuel Corrales for useful comments. This document has been produced within the framework of the "Tropical Forests and Climate Change Adaptation" (TroFCCA) project executed by CATIE and CIFOR and funded by the European Commission under contract EuropeAid/ENV/2004-81719. The contents of this document are the sole responsibility of the authors and can under no circumstances be regarded as reflecting the position of the European Union.

Open Access This article is distributed under the terms of the Creative Commons Attribution Noncommercial License which permits any noncommercial use, distribution, and reproduction in any medium, provided the original author(s) and source are credited.

\section{References}

Andreassian V (2004) Water and forests: from an historical controversy to scientific debate. J Hydrol 291:1-27

Bonell M, Bruijnzeel LA (eds) (2005) Forests, water and people in the humid tropics: past, present and future hydrological research for integrated land and water management. Cambridge University Press, Cambridge

Bosch JM, Hewlett JD (1982) A review of catchment experiments to determine the effect of vegetation changes on water yield and evapotranspiration. J Hydrol 55:3-23

Bruijnzeel LA (2001) Hydrology of tropical montane cloud forests: a reassessment. Land Use Water Resour Res 1:1-18 
Bruijnzeel LA (2004) Hydrological functions of tropical forests: not seeing the soil for the trees? Agric Ecosyst Environ 104:185-228

Calder IR (2002) Forests and hydrological services: reconciling public and science perceptions. Land Use Water Resour Res $2: 1-12$

Carpenter SR, Turner M (2000) Opening the black boxes: ecosystem science and economic valuation. Ecosystems 3:1-3

CEPAL (2006) Istmo Centroamericano: estadísticas del subsector eléctrico. Naciones Unidas, CEPAL (Comisión para América Latina y el Caribe), report LC/MEX/L.710, 18 April 2006, México

Chee YE (2004) An ecological perspective on the valuation of ecosystem services. Biol Conserv 120:549-565

Costanza R, d'Arge R, de Groot RS, Farber S, Grasso M, Hannon B, Limburg K, Naeem S, O’Neill RV, Paruelo J, Raskin RG, Sutton P, van den Belt M (1997) The value of the world's ecosystem services and natural capital. Nature 387:253-260

Cox E (1994) The fuzzy systems handbook: a practitioner's guide to building, using, and maintaining fuzzy systems. Academic Press, pp 667

Daily G (ed) (1997) Nature's services: societal dependence on natural ecosystems. Island Press, Washington, DC

Daly HE, Farley JF (2004) Ecological economics: principles and applications. Island Press, Washington, DC

Droesen WJ (1996) Formalisation of ecohydrological expert knowledge applying fuzzy techniques. Ecol Model 85:75-81

Eade JDO, Moran D (1996) Spatial economic valuation: benefits transfer using geographical information systems. J Environ Manage 48:97-110

Egoh B, Rouget M, Reyers B, Knight AT, Cowling RM, van Jaarsveld AS, Welz A (2007) Integrating ecosystem services into conservation assessments: a review. Ecol Econ 63:714-721

Egré D, Milewski JC (2002) The diversity of hydropower projects. Energ Policy 30:1225-1230

Ferraro PJ (2004) Targeting conservation investments in heterogeneous landscapes: a distance-function approach and application to catchment management. Am J Agr Econ 86(4):905-918

Freeman AM (2003) The measurement of environmental and resource values: theory and methods, 2nd edn. Resources for the Future, Washington, DC

Frey GW, Linke DJ (2002) Hydropower as a renewable and sustainable energy resource meeting global energy challenges in a reasonable way. Energ Policy 30:1261-1265

Gren IM, Svensson L, Carlsson M, Bishop K (2010) Policy design for a multifunctional landscape. Reg Environ Change doi:10.1007/ s10113-009-0105-9

Griesinger B, Gladwell J (1993) Hydrology and water resources in tropical Latin America and the Caribbean. In: Bonell $\mathrm{M}$, Hufschmidt M, Gladwell J (eds) Hydrology and water management in the humid tropics: hydrological research issues and strategies for water management, Cambridge University Press, Cambridge, pp 84-97

Guo Z, Xiao X, Li D (2000) An assessment of ecosystem services: water flow regulation and hydroelectric power production. Ecol Appl 10(3):925-936

Hanss M (2005) Applied fuzzy arithmetic: an introduction with engineering applications. Springer, Berlin

Heal GM, Barbier EB, Boyle KJ, Covich AP, Gloss SP, Hershner CH, Hoehn JP, Pringle CM, Polasky S, Segerson K, SchraderFrechette K (2004) Valuing ecosystem services: toward better environmental decision-making. The National Academies Press, Washington, DC

Hein L, van Koppen K, de Groot RS, van Ierland EC (2006) Spatial scales, stakeholders and the valuation of ecosystem services. Ecol Econ 57:209-228
Hijmans RJ, Cameron SE, Parra JL, Jones PG, Jarvis A (2005) Very high resolution interpolated climate surfaces for global land areas. Internat J Climatol 25(15):1965-1978

Ilstedt U, Malmer A, Verbeeten E, Murdiyarso D (2006) Infiltration change after forest disturbance and conversion to other land uses in the tropics: a systematic review and meta-analysis. In: Liu S, Sun G, Sun P (eds) International conference on forest and water in a changing environment, Beijing, pp 194-197

ITCR (2004) Atlas Digital de Costa Rica 2004, Escuela de Ingeniería Forestal. Instituto Tecnológico de Costa Rica, Cartago, Costa Rica

Kaimowitz D (2005) Useful myths and intractable truths: the politics of the link between forests and water in Central America. In: Bonell M, Bruijnzeel LA (eds) Forests, water and people in the humid tropics: past, present and future hydrological research for integrated land and water management. Cambridge University Press, Cambridge, pp 86-98

Kragt ME, Newham LTH, Bennett J, Jakeman AJ (2010) An integrated approach to linking economic valuation and catchment modelling. Environ Model Softw doi: 10.1016/j.envsoft. 2010.04 .002 (in press)

Kremen C (2005) Managing ecosystem services: what do we need to know about their ecology? Ecol Lett 8:468-479

Lawry J (2006) Modelling and reasoning with vague concepts. Springer, New York

Limburg KE, O’Neill RV, Costanza R, Farber S (2002) Complex systems and valuation. Ecol Econ 41:409-420

Locatelli B, Vignola R (2009) Managing catchment services of tropical forests and plantations: can meta-analyses help? Forest Ecol Manag 258(9):1864-1870

MagFor (2002) Atlas rural de Nicaragua. CIAT, Magfor, Inec, Ciat, Ineter, Marena, Managua, Nicaragua

Metzger MJ, Schröter D (2006) Towards a spatially explicit and quantitative vulnerability assessment of environmental change in Europe. Reg Environ Change 6:201-216

Metzger MJ, Schröter D, Leemans R, Cramer W (2008) A spatially explicit and quantitative vulnerability assessment of environmental change in Europe. Reg Environ Change 8:91-107

Meyerson LA, Baron J, Melillo JM, Naiman RJ, O’Malley RI, Orians G, Palmer MA, Pfaff AS, Running SW, Sala OE (2005) Aggregate measures of ecosystem services: can we take the pulse of nature? Front Ecol Environ 3(1):56-59

Millennium Ecosystem Assessment (2003) Ecosystems and human well-being: a framework for assessment. Island Press, Washington

Millennium Ecosystem Assessment (2005) Synthesis report. Island Press, Washington, DC

Mulligan M, Burke SM (2005) DFID FRP project ZF0216 global cloud forests and environmental change in a hydrological context. Final report. December 2005. http://www.ambiotek. com/cloudforests

Muñoz JR, Sailor DJ (1998) A modelling methodology for assessing the impact of climate variability and climatic change on hydroelectric generation. Energy Conserv Manage 39(14): $1459-1469$

Mwakalila S (2003) Estimation of stream flows of ungauged catchments for river basin management. Phys Chem Earth 28:935-942

Naidoo R, Ricketts TH (2006) Mapping the economic costs and benefits of conservation. PLOS Biol 4(11):2153-2164

Naidoo R, Balmford A, Costanza R, Fisher B, Green RE, Lehner B, Malcolm TR, Ricketts TH (2008) Global mapping of ecosystem services and conservation priorities. PNAS 105(28):9495-9500

Phillis YA, Andriantiatsaholiniaina LA (2001) Sustainability: an illdefined concept and its assessment using fuzzy logic. Ecol Econ $37: 435-456$ 
Polasky S, Nelson E, Lonsdorf E, Fackler P, Starfield A (2005) Conserving species in a working landscape: land use with biological and economic objectives. Ecol Appl 15(4):1387-1401

Raymond CM, Bryan BA, MacDonald DH, Cast A, Strathearn S, Grandgirard A, Kalivas T (2009) Mapping community values for natural capital and ecosystem services. Ecol Econ 68:1301-1315

Sahin V, Hall MJ (1996) The effects of afforestation and deforestation on water yields. J Hydrol 178:293-309

Southgate D, Macke R (1989) The downstream benefits of soil conservation in third world hydroelectric catchments. Land Econ 65(1):38-48

Strayer DL, Ewing HA, Bigelow S (2003) What kind of spatial and temporal details are required in models of heterogeneous systems? Oikos 102:654-662

TNC (2007) Red de Drenajes de Centroamérica, Geodatabase. Versión 1.0. The Nature Conservancy, Región de Mesoamérica \& Caribe. Science Program, San José, Costa Rica

Tomich TP, Thomas DE, van Noordwijk M (2004) Environmental services and land use change in Southeast Asia: from recognition to regulation or reward? Agric Ecosyst Environ 104:229-244

Troy A, Wilson MA (2006) Mapping ecosystem services: practical challenges and opportunities in linking GIS and value transfer. Ecol Econ 60:435-449

van der Horst D (2006) Spatial cost-benefit thinking in multifunctional forestry; towards a framework for spatial targeting of policy interventions. Ecol Econ 59:171-180 van Jaarsveld AS, Biggs R, Scholes RJ, Bohensky E, Reyers B, Lynam T, Musvoto C, Fabricius C (2005) Measuring conditions and trends in ecosystem services at multiple scales: the Southern African Millennium Ecosystem Assessment (SAfMA) experience. Phil Trans R Soc B 360:425-441

van Noordwijk M, Poulsen JG, Ericksen PJ (2004) Quantifying offsite effects of land use change: filters, flows and fallacies. Agric Ecosyst Environ 104:19-34

Veloz A, Southgate D, Hitzhusen F, Macgregor R (1985) The economics of erosion control in a subtropical catchment: a Dominican case. Land Econ 61(2):145-155

Wagener T, Sivapalan M, McDonnell J, Hooper R, Lakshmi V, Liang $\mathrm{X}$, Kumar P (2004) Predictions in ungauged basins as a catalyst for multidisciplinary hydrology. Eos Trans AGU 85:451-453

Wang WJ, Luoh L (2000) Simple computation for the defuzzifications of center of sum and center of gravity. J Intell Fuzzy Syst 9:53-59

Wünscher T, Engel S, Wunder S (2008) Spatial targeting of payment for environmental services: a tool for boosting conservation benefits. Ecol Econ 65:822-833

Yang W, Khanna M, Farnsworth R, Onal H (2003) Integrating economic, environmental and GIS modeling to target cost effective land retirement in multiple catchments. Ecol Econ 46:249-267

Zadeh LA (1965) Fuzzy sets. Inform Control 8:338-353 